\title{
Geochemistry of layered kyanite-bearing eclogites from the Roberts Victor Mine, South Africa
}

\author{
Jacob, D.E. ${ }^{1}$ and Mattey, D.P. ${ }^{2}$
}

1. Mineralogisch-Petrologisches Institut, University of Göttingen, Goldschmidtsr.1, D-37077 Göttingen, Germany

2. Department of Geology, Royal Holloway University of London, Egham, Surrey TW20 OEX, Great Britain

Kyanite-bearing eclogites and grospydites are often members of kimberlitic xenolith suites. Although generally non-diamondiferous, some rare diamondiferous grospydites and kyanite eclogites have been described from the Udachnaya kimberlite pipe in Siberia (Ponomarenko et al., 1975). Heterogeneous kyanite eclogites and grospydites often show bands of modally different eclogite, typically with sharp compositional variation between the layers of different mineralogy (Hatton, 1978). These sharp interfaces also show up in the composition of the garnets across the layers, and were among the reasons to propose a process of liquid immiscibility for the genesis of these rocks (e.g. Hatton and Gurney, 1977). Other research groups proposed that the layers could be remnants of premetamorphic primary differences (Jacob and Jagoutz, 1995). This was based mainly on the following facts: (1) the studied layered eclogite belongs to the $2.7 \mathrm{Ga}$ old suite of eclogites at Roberts Victor of subducted origin (Jagoutz et al., 1984), and (2) the bulk composition of kyanite eclogites is anorthositic. Thus, kyanite eclogite could have been an anorthositic cumulate within the Archean oceanic crust. Lappin and Dawson (1975) proposed a cumulate origin for the kyanite eclogites of Roberts Victor from an evolved high P-magma at $1400-1500^{\circ} \mathrm{C}, 26-28 \mathrm{kbar}$ followed by stages of partial melting and chemical exchange with the ascending kimberlitic magma.

We have studied several non-diamondiferous layered kyanite eclogites from the Roberts Victor Mine in terms of major and trace elements as well as oxygen isotopes. Major elements were measured at the University at Frankfurt, Germany, on a Jeol JXA 8900 microprobe using WDS, trace element concentrations were measured in situ by Laser Ablation ICP-MS at the Memorial University in St. John's, Newfoundland.

\section{Sample description}

From the three studied samples, one has been described previously: Rovic 124 (Jacob and Jagoutz, 1995) is a layered eclogite which contains abundant diamond in the top, garnet rich layer. Although this specimen is not kyanite bearing, a single kyanite inclusion was extracted from a diamond from this rock (N.V. Sobolev, pers. comm. 1994).

BD 1168 and BD 1987, both kindly provided by Barry Dawson, have not been described previously. These two samples consist each of two layers, of which one is kyanite-bearing, with sharp interfaces between the two layers. Kyanite is relatively abundant in both specimens and amounts to about 25$30 \%$ in BD 1168 and 15-20\% in BD 1987.

Clinopyroxenes in the more $\mathrm{CaO}$ rich parts of Rovic 124 and in all other samples is very altered, but small areas of fresh, clear minerals can be found within the altered grains.

\section{Geochemistry}

Typically, the composition of garnets changes abruptly between the layers, e.g. in BD1168 from 9.90 wt $\% \mathrm{CaO}$ in the kyanite-free layer to $16.20 \mathrm{wt} \% \mathrm{CaO}$ in the kyanite-bearing part. Changes in chemistry also include many trace elements, especially the heavy rare earth elements (HREE, Fig.1) and the compatible trace elements.

Trace element concentrations measured by Laser Ablation ICP-MS are shown as a chondritenormalized spidergram for garnets from sample BD 1168. It can be seen that garnets from the kyanitebearing layer of the sample generally have lower abundances of HREE compared to garnets from the kyanite-free layer. The chondrite-normalized REE abundances of this sample are very similar to those of the group I Udachnaya eclogites (Jacob and Foley, 1998), although $\delta^{18} \mathrm{O}$ values for those are lower 
than the mantle value, whereas $\delta^{18} \mathrm{O}$ values for South African kyanite eclogites are higher than the mantle value.

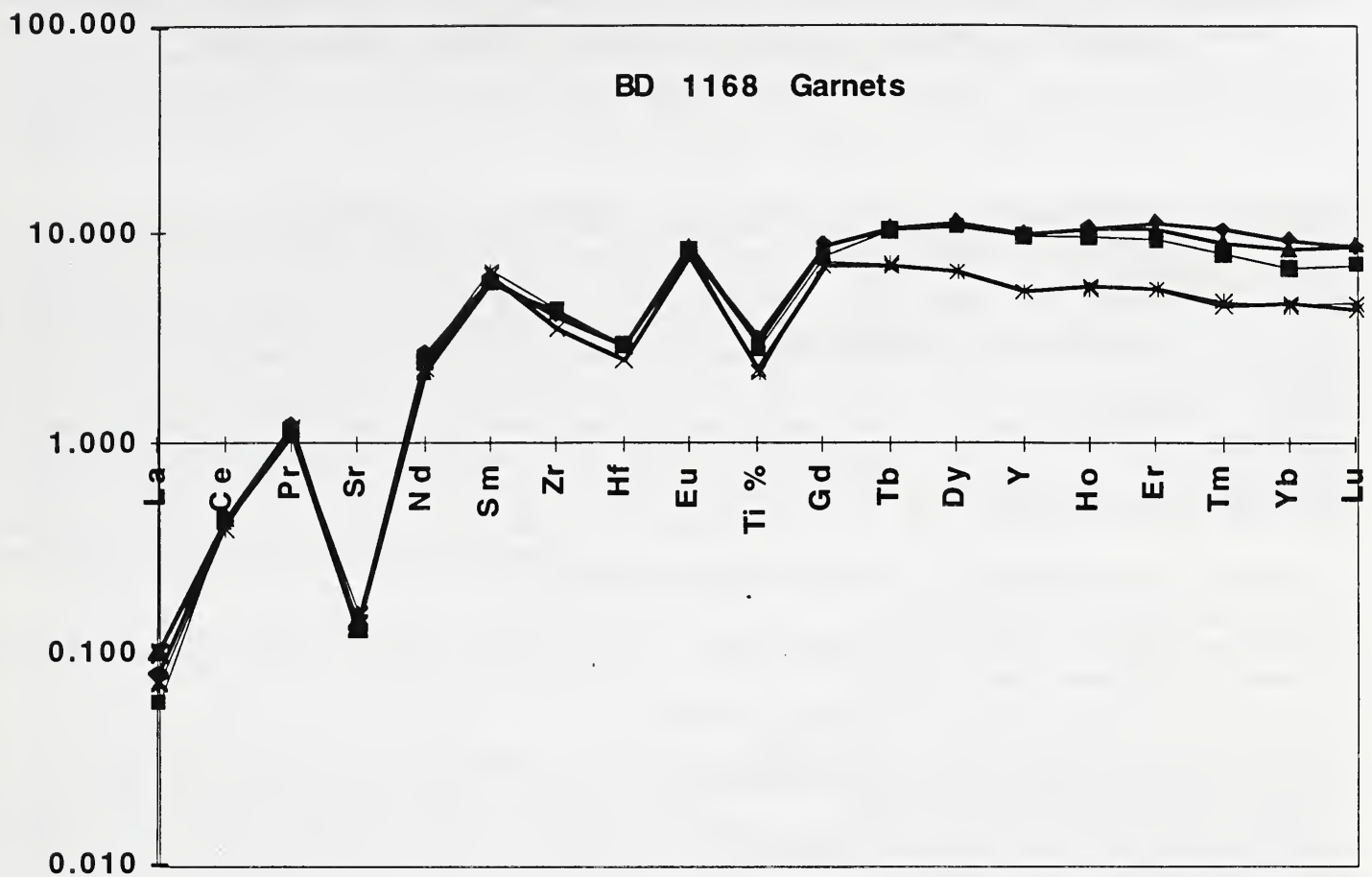

Fig.1 Chondrite-normalized trace element concentrations of garnets from different layers in sample BD 1168. Note the lower abundances of HREE and Ti in the kyanite-bearing layer (crosses). Positive Eu-anomalies, however, exist in both layers.

\section{References}

Hatton, C.J., 1978, The geochemistry and origin of xenoliths from the Roberts Victor mine, Ph.D. Thesis, Univ. of Cape Town.

Hatton, C.J. and Gurney, J.J., 1977, Kyanite eclogites from the Roberts Victor Mine, Ext. Abstr. 2nd Intern. Kimberlite Conf.

Jacob, D.E. and Foley, S.F., 1998, Evidence for Archean Ocean Crust with Island Arc Signature from Diamondiferous Eclogite Xenoliths, this volume.

Jacob, D. and Jagoutz, E., 1995, A diamond-graphite bearing eclogitic xenolith from Roberts Victor (South Africa): Indications for petrogenesis from $\mathrm{Pb}-, \mathrm{Nd}-$ and $\mathrm{Sr}$ - isotopes, Proc. 5th Intern. Kimberlite Conf., CPRM Spec. Publ. 1/95, p. 304-317.

Jagoutz, E., Dawson, J. B., Hoernes, S., Spettel, B. and Wänke, H., 1984, Anorthositic oceanic crust in the Archean Earth: 15th Lunar Planet. Sci. Conf. , 395-396. (abs).

Lappin, M.A. and Dawson, B.D., 1975, Two Roberts Victor cumulate eclogites and their reequilibration, Phys. Chem. Earth 9, 351-365.

Ponomarenko, A.I., Sobolev, N.V., Pokhilenko, N.P., Lavrent'yev, Y.G. and Sobolev, V.S., 1976, Diamond-bearing grospidite and diamond-bearing kyanite eclogite from the Udachnaya kimberlite, Yakutia, Dokl. Akad. Nauk SSSR, 226, 158-161.

Smyth, J.R. and Hatton, C.J., 1977, A coesite-sanidine grospydite from the Roberts Victor kimberlite, Earth Planet. Sci. Lett. 34, 284-290. 